\title{
Tuberous sclerosis complex: the past and the future
}

\author{
Liesbeth De Waele • Lieven Lagae • Djalila Mekahli
}

Received: 30 April 2014 /Revised: 25 November 2014 / Accepted: 1 December 2014 /Published online: 23 December 2014

(C) IPNA 2014

\begin{abstract}
Renal lesions represent the second most significant cause of morbidity and mortality in patients with tuberous sclerosis complex (TSC). Recent advances in the understanding of the pathophysiology of TSC have led to the exploration of new potential therapeutic targets. Clinical trials with mammalian target of rapamycin (mTOR) inhibitors have demonstrated promising results for several indications, such as renal angiomyolipoma, subependymal giant cell astrocytoma, lymphangioleiomyomatosis and facial angiofibromas. Currently, there is a scarcity of natural history data and randomized, placebo-controlled clinical trials on TSC. Recently, however, recommendations for the diagnostic criteria, surveillance, and management of TSC patients have been updated. This review focuses on these novel recommendations and highlights the need for multidisciplinary follow-up of this multi-systemic disease.
\end{abstract}

Keywords Tuberous sclerosis complex $\cdot$ Renal cysts . Angiomyolipoma $\cdot \mathrm{mTOR} \cdot \mathrm{mTOR}$ inhibitor

\begin{tabular}{|c|c|}
\hline \multicolumn{2}{|c|}{ Abbreviations } \\
\hline ACEi & Angiotensin-converting enzyme inhibitor \\
\hline CKD & Chronic kidney disease \\
\hline CT & Computed tomography \\
\hline
\end{tabular}

L. De Waele · L. Lagae

Department of Pediatric Neurology, University Hospitals Leuven, Herestraat 49, 3000 Leuven, Belgium

L. De Waele $(\bowtie) \cdot$ L. Lagae $\cdot$ D. Mekahli

Department of Development and Regeneration, KU Leuven, Leuven, Belgium

e-mail: liesbeth.dewaele@uzleuven.be

D. Mekahli

Department of Pediatric Nephrology, University Hospitals Leuven, Herestraat 49, 3000 Leuven, Belgium

$\begin{array}{ll}\text { ESRD } & \text { End-stage renal disease } \\ \text { LAM } & \text { Lymphangioleiomyomatosis } \\ \text { MRI } & \text { Magnetic resonance imaging } \\ \text { mTOR } & \text { Mammalian target of rapamycin } \\ \text { mTORi } & \text { Mammalian target of rapamycin inhibitor } \\ \text { PKD } & \text { Polycystic kidney disease } \\ \text { RCC } & \text { Renal cell carcinoma } \\ \text { SEGA } & \text { Subependymal giant cell astrocytoma } \\ \text { SEN } & \text { Subependymal nodule } \\ \text { TAND } & \text { TSC-associated neuropsychiatric disorders } \\ \text { TSC } & \text { Tuberous sclerosis complex }\end{array}$

\section{Introduction}

Tuberous sclerosis complex (TSC) is an autosomal dominant genetic syndrome characterized by a predisposition to benign tumor (hamartoma) formation. It is caused by mutations in the genes TSC1 (OMIM 605284; located on chromosome 9q34) and TSC2 (OMIM 191092; located on chromosome 16p13.3), encoding for the proteins hamartin and tuberin respectively [1, 2]. This disorder affects approximately 1 in 6,000 individuals involving all racial and ethnic groups. Since the identification of the genes in the 1990s, more than 300 allelic variants of $T S C 1$ and more than 1,000 allelic variants of TSC2 have been reported. Mutations in TSC2 are more common (50\%) and associated with a more severe phenotype than those in TSC1 (20\%) [3]. TSC can be inherited as an autosomal dominant disorder, but two thirds of patients have de novo mutations.

Tuberous sclerosis complex is characterized by the formation of hamartomas in multiple organ systems, including the skin, the brain, the heart, the kidneys, the eyes, and the lungs, with a wide diversity of symptoms and severity across patients $[3,4]$. Although there is a scarcity of natural history data and randomized, placebo-controlled clinical trials in TSC, 
especially in the pediatric population, the 2012 International TSC Consensus group has recently updated the diagnostic criteria [5], and the recommendations for surveillance and management of patients with TSC [6]. Moreover, a few clinical trials using mammalian target of rapamycin inhibitors (mTORi) have shown promising results for several indications in adults and children with TSC. This overview puts the spotlight on the most significant changes in the updated recommendations for TSC emphasizing key points for making decisions about patient care.

\section{Methodology}

A medical literature search was performed in April 2014 using the PubMed database of all articles published in English. Search terms consisted of "tuberous sclerosis complex" or "TSC" AND "review," "angiomyolipoma," "renal involvement," "renal cyst,", "chronic kidney disease (CKD)," "endstage renal disease (ESRD)," "hypertension," "renal tumors," "RCC," "contiguous gene deletion syndrome", "mTOR inhibitor" or "rapamycin." We aimed to discuss the new recommendations based on the available literature and the publications of the 2012 International TSC Consensus Group [5, 6].

\section{Renal involvement in TSC}

About $80-90 \%$ of TSC patients have renal manifestations by adulthood $[3,7,8]$, representing the second most significant cause of morbidity and mortality in all ages combined, and the most common cause of mortality after the age of 30 years [8]. Renal lesions in TSC consist of renal cysts, angiomyolipomas, fat-poor lesions, and malignant tumors, causing CKD. There is a clear correlation between the presence of renal abnormalities (angiomyolipomas and renal cysts) and age. Renal lesions are observed in $38.5-55 \%$ of children at preschool age ( $\leq 6$ years), increasing to $75-80 \%$ in the school age group, and reaching $86-100 \%$ in adults $[9,10]$. Very little is known in adult and even less in pediatric TSC patients about the natural history of these renal lesions, about the incidence of CKD and ESRD, and about renal co-morbidities such as hypertension and proteinuria.

\section{Angiomyolipoma}

Renal angiomyolipomas are benign tumors composed of abnormal blood vessels, immature smooth muscle cells, and mature adipose tissue. Angiomyolipomas occur in 55-80\% of patients $[4,5,11]$ and are the most common cause of TSCrelated morbidity in adults. They often appear as multiple and bilateral tumors with rapid growth in childhood and adolescence that stabilizes throughout adulthood [9, 12-17]. It has even been suggested that angiomyolipomas might appear as early as infancy [18]. The abnormal vasculature in angiomyolipomas is frequently associated with the development of micro- and macro-aneurysms, putting both children and adults with TSC at risk of spontaneous, possibly lifethreatening, hemorrhage [19-23]. This risk is estimated to be $25-50 \%[16,24,25]$, with up to $20 \%$ of patients presenting with hypovolemic shock [25]. Risk factors for bleeding from angiomyolipomas are tumor size $(>4 \mathrm{~cm})$, growth as assessed by serial measurements, and aneurysm size $(>0.5 \mathrm{~cm})[8,26$, 27]. Nowadays, the management of active bleeding from angiomyolipomas consists of arterial embolization, sometimes even prophylactic. Unfortunately, most often unnecessarily, partial or total nephrectomy is still performed $[8,28]$.

\section{Renal cysts}

Renal cysts occur in $30-45 \%$ of TSC patients, both in TSC1and TSC2-related disease $[11,12,18]$. The cystic lesions vary from microcystic involvement not detectable by imaging, to multiple large cysts. Also, glomerulocystic kidney disease has been described in TSC patients [29, 30]. A severe, very early onset polycystic kidney disease (PKD) phenotype is mostly caused by deletions involving the adjacent TSC2 and PKD1 genes on chromosome 16p13, causing the so-called TSC2/ PKD1 contiguous gene deletion syndrome [31-33]. Despite the lack of data on the renal outcome of these patients, it has been reported that the TSC2/PKD1 syndrome occurs in about 2$5 \%$ of TSC patients, and results in significant renal insufficiency in teenage years [33]. Recently, it has been suggested that TSC can also be classified as a ciliopathy associated with renal cysts.

\section{Fat-poor renal lesions}

There is a lack of information about fat-poor renal lesions in TSC patients, since they are very difficult to detect with ultrasound. They consist mainly of spindle cells, epithelioid cells or vascular elements, with a varying contribution of each cell type. Solid fat-poor lesions in the kidneys of a patient with TSC are most often angiomyolipomas, but they can occasionally be oncocytomas or renal cell carcinomata (RCC). Oncocytomas occur more frequently in TSC than in the general population, where they are uncommon benign adenomatous hamartomas accounting for only $3-5 \%$ of renal parenchymal tumors [34]. They arise from the intercalated cells of the cortical portion of the collecting duct [35], and consist of dense eosinophilic cytoplasm with generally uniform nuclei and abundant mitochondria [36, 37]. RCC occurs in 3-5\% of patients with TSC at an average age of 28-50 years, with very few reports in childhood [38, 39]. However, not all reported RCC cases have been studied in detail (e.g., histology) with possible misclassifications. Magnetic resonance imaging (MRI) is the best imaging method for detecting fat-poor 
lesions. However, there are currently no imaging methods that clearly distinguish a fat-poor angiomyolipoma from an RCC. Patel et al. suggested that the growth rate might help to differentiate these lesions [40]. A diagnostic needle biopsy has been recommended for fat-poor lesions growing faster than $0.5 \mathrm{~cm}$ per year to distinguish RCC from angiomyolipoma [6]. The typical hematoxylin and eosin appearance of RCC is very similar to the epithelioid variant of angiomyolipoma and may lead to misdiagnosis. The discovery of human melanoma black-45 (HMB-45) and other melanocytic markers such as melanin-A, has increased the reliability of the biopsies. Virtually all angiomyolipomas stain positive for these antibodies, and RCC stains negative, making immunohistochemistry extremely important in excluding RCC [28].

\section{Nephrolithiasis}

Hypocitraturia represents the main risk factor for nephrolithiasis in TSC patients and is due either to a disruption of distal tubular function secondary to renal cysts, or is a consequence of a ketogenic diet or topiramate use for the management of seizures. Adequate hydration and citrate supplementation are used to prevent or treat this complication [41].

\section{Renal outcome}

Almost no information is available in the literature regarding the long-term renal outcome of adult TSC patients, and even less is known regarding the pediatric population. Children with TSC are almost always born with normal kidneys and normal kidney function, but they develop renal lesions for which they undergo renal surgery (often unnecessarily) throughout their life, contributing to nephron loss. No data are available on the incidence of CKD in this population; only a few case reports of renal transplantation in TSC adults have been described $[42,43]$. CKD and ESRD in TSC patients are mainly due to renal parenchymal loss secondary to angiomyolipoma and cyst growth, hemorrhage, and more significant surgery. Moreover, patients with TSC are exposed to renal injury by medication (anticonvulsants and nonsteroidal inflammatory drugs), rhabdomyolysis, and hypoxia induced by prolonged seizures [44]. This may also contribute to the acceleration of the loss of renal function. CKD and renal failure represent a major burden in these patients and are the leading cause of death in adult patients with TSC $[28,45,46]$.

No clear data are found in the literature regarding the incidence of hypertension in the TSC population [41]. Recent data on PKD patients demonstrated the benefit of good blood pressure control on renal prognosis in adults [47] and in children [48]. Also, a clear correlation has been described between high blood pressure, high serum renin levels, renal volume, and disease progression. The role of ACEi has been highlighted and ACEi became the treatment of choice in this population [47]. Better control of blood pressure and overall better patient care has resulted in a trend toward the prolonged preservation of renal function in renal cystic disease [49]. Based on this, it has been suggested that the diagnosis and management of hypertension might represent very important factors in the follow-up of TSC patients. No data are available regarding the treatment of choice for hypertension, regarding neither the incidence of proteinuria nor the effect of long-term use of ACEi in TSC. However, we would like to highlight the increased incidence of angioedema in patients treated with the combination of ACEi and mTORi [50]. This needs to be further elucidated in a large TSC cohort.

\section{Extrarenal manifestations in TSC}

Neurological manifestations

Brain lesions in TSC mainly consist of cortical tubers, subependymal nodules (SENs), and subependymal giant cell astrocytomas (SEGAs). They are the leading cause of morbidity and mortality in TSC. Cortical tubers, occurring in $90 \%$ of TSC patients, are severe malformations of cortical development (focal cortical dysplasia) with complete disruption of the normal laminar organization of the cerebral cortex, occurring most frequently at the junction of gray and white matter. They are considered to be a cause of epilepsy, autism, and learning difficulties in patients with TSC, but some evidence suggests functional abnormalities in brain regions without tubers [51]. SENs are benign growths along the ependymal lining of the lateral and third ventricles, observed in $80 \%$ of individuals with TSC, and often detected prenatally or at birth [5]. SEGAs are low-grade brain tumors that develop from SENs in only a minority of TSC patients (5-15\%) [52]. Usually, they grow during childhood and adolescence, being the major cause of morbidity and mortality in this age group [53-55]. Although these lesions are generally benign and noninfiltrative, they can be life-threatening as they arise typically near the foramen of Monro, unilaterally or bilaterally. Serial growth may result in acute or subacute obstructive hydrocephalus [56] and sudden death [57].

Although a subset of patients with TSC has normal cognition [3], seizures, intellectual disability, developmental delay, and TSC-associated neuropsychiatric disorders (TAND) are well-known manifestations in children and adults with TSC. Epileptic seizures occur in 85-90 \% of patients and are associated with neurodevelopmental and cognitive problems [4, 58]. Epilepsy generally begins during the first year of life and most often consists of focal seizures and/or infantile spasms [3, 59]. Management is challenging and one third of the patients remain refractory to therapy, despite extensive 
pharmacological and non-pharmacological treatments such as surgery, ketogenic diet, and vagus nerve stimulation $[3,59$, 60]. Cognition declines with the onset of infantile spasms, which are often responsive to vigabatrin. TAND include aggressive behavior, autism spectrum disorder (20-40\%), attention deficit and hyperactivity disorder, intellectual disabilities, sleeping difficulties, psychiatric disorders, and neuropsychological deficits, as well as school and occupational difficulties [61-63].

Lung involvement

Lymphangioleiomyomatosis (LAM) is characterized by the proliferation of smooth muscle cells and cystic changes within the lung parenchyma. Almost exclusively adolescent girls and women (up to $80 \%$ by the age of 40) are affected [64], presenting with progressive dyspnea on exertion, hemoptysis, and recurrent pneumothoraces in the third to fourth decade of life. Symptomatic LAM is very rare in male patients with TSC. Chest radiographs reveal a diffuse reticular pattern and high-resolution computed tomography of the chest shows diffuse interstitial changes with infiltrates and cystic changes. Some individuals progress to respiratory failure and death. Other manifestations of TSC in the lung include multifocal micronodular pneumocyte hyperplasia (MMPH, 40-85\%) and clear cell tumor of the lung [65].

\section{Others}

Tuberous sclerosis complex can affect virtually any organ in the body. Cardiac rhabdomyomas, mostly located in the ventricles, are highly specific to TSC (75-80\% risk of TSC) [66, 67]. They are often the first noted manifestation of the disease on the prenatal ultrasound of affected fetuses (47-67\%), and most often regress after birth and eventually disappear. They may compromise ventricular function, interfere with valve movement or result in outflow obstruction, and they are also associated with cardiac arrhythmias [5]. Skin manifestations in TSC, detected in almost $100 \%$ of patients at all ages, include hypomelanotic macules $(87-100 \%$ of individuals, formerly known as ash-leaf spots), facial angiofibromas (47$90 \%$, formerly called adenoma sebaceum), shagreen patches (20-80\%), fibrous cephalic plaques (25\%), and ungual fibromas (17-87\%) [5]. Confetti skin lesions (3-58\%), dental enamel pits (up to $100 \%$ in adults), and intraoral fibromas (20-50\%) are described as minor features [5]. Retinal hamartomas are observed in $30-50 \%$ of TSC patients, and retinal achromic (hypopigmented) patches in $39 \%$. Unless they involve the macula or optic nerve, ophthalmic lesions are usually asymptomatic. Hepatic angiomyolipomas are described in 10-25\% of TSC patients [68].

\section{Pathophysiology and treatment targets}

Briefly, both TSC1 and TSC2, encoding for the proteins hamartin and tuberin respectively, act as tumor suppressor genes. It has been reported that the inactivation of both alleles of $T S C 1$ or $T S C 2$ is required for tumor formation: in addition to a germinal mutation, a second, somatic mutation ("second hit hypothesis") has to occur, resulting in a complete loss of function [69]. This loss of heterozygosity is shown in the majority of hamartomas in TSC (mainly in angiomyolipoma, sporadic in LAM and SEGA), but is interestingly only rarely found in the cortical tubers [70]. The proteins hamartin and tuberin form an intracellular heterodimer protein complex TSC1/TSC2 interacting with a variety of other proteins. This TSC1/TSC2 protein complex converts the Ras homolog enriched in the brain-GTP to the inactive form, inactivating the mammalian target of rapamycin (mTOR) [71, 72]. mTOR is a highly conserved protein kinase that regulates protein synthesis, cellular metabolism, differentiation, growth and proliferation. A complete loss of hamartin or tuberin results in an unregulated activation of mTOR with subsequent uncontrolled cell growth and proliferation. The significant advances in understanding of the pathophysiological pathways linking gene mutations and hamartoma formation led to the exploration of mTORi, such as rapamycin (sirolimus) and RAD001 (everolimus), as a therapeutic strategy to treat TSC-related tumors. These agents had already been used for many years as immunosuppressants in solid organ transplantation [73] and cancer treatment (e.g. RCC) [74], and more recently in PKD [75]. It has been demonstrated in preclinical studies that mTORi effectively reduce cell proliferation and tumor size in animal models and patient-derived cell lines of TSC [76]. These encouraging results have opened perspectives for drug intervention in TSC patients for different indications including SEGAs, renal angiomyolipomas, pulmonary LAM, epilepsy and facial angiofibromas.

\section{Updated recommendations for the diagnosis and surveillance of TSC}

Despite the significant advances in understanding of the underlying molecular pathology of TSC, and the development of new treatment options with mTORi in the last decade, the international consensus recommendations about the diagnosis and management of TSC date back to 1998 [77]. Recently, the 2012 International TSC Consensus group has updated the recommendations for the diagnostic criteria, surveillance, and management of TSC patients [5,6]. The implementation of these recommendations will facilitate and improve the care for this specific population, with a potential better clinical 
outcome. We next discuss the adjustments to the recommendations, and the results of the clinical trials with mTORi. These recommendations are available at www.tsalliance.org/ consensus.

\section{Recommendations for TSC diagnostic criteria}

The most significant change to the diagnostic criteria was the introduction of genetic testing, which is currently widely available. A "pathogenic mutation" in $T S C 1$ or TSC2 that compromises protein synthesis and/or inactivates its function, has become an independent diagnostic major criterion, sufficient for the diagnosis of TSC. Other genetic variants with less certain functional effect are not considered to be major criteria [5]. We need to emphasize that in 10-25\% of TSC patients no mutation can be found in either TSC1 or TSC2, which does not exclude the diagnosis. Furthermore, the diagnostic classes have been reduced to "possible" and "definite," and the 11 major and 9 minor features described by the 1998 conference were reduced to 11 major and only 6 minor features (Table 1). Additionally, minor clarifications and simplifications were made to some specific criteria [5, 6]. A definite diagnosis of TSC is made if two major features, or one major feature with at least two minor features are present. A TSC diagnosis is possible in the presence of either one major feature or at least two minor features $[5,6]$.

\section{Recommendations for the surveillance of TSC patients}

The 2012 TSC consensus was made relevant to the entire lifespan of TSC patients, from infancy to adulthood, for newly diagnosed patients, and for those in follow-up with an established diagnosis. We would like to focus on the recommendations for the surveillance and management of renal lesions [6]. Although ultrasound and computed tomography (CT) are adequate for the detection of the adipose component of angiomyolipomas, fat-poor lesions can be missed [78, 79]. It has been suggested that MRI is superior to ultrasound and $\mathrm{CT}$, and represents the preferred evaluation modality for angiomyolipomas (especially fat-poor lesions) [15, 80, 81] in newly diagnosed patients, and for 1- to 3-yearly follow-up throughout their lifetime $[5,6]$. This can be performed during the same session as the brain MRI to limit the need for anesthesia. Furthermore, MRI may also detect vascular aneurysms and extrarenal hamartomas in other abdominal organs. In addition to imaging, evaluation of blood pressure and renal function is recommended at diagnosis and at least annually during follow-up [5, 6]. Although the value of ACEi as the first choice of treatment for hypertension is not validated, the Consensus group recommends it as first-line therapy in TSC patients [6]. However, the combination of treatment with ACEi and mTORi should be avoided. Duerr et al. reported a higher incidence of angioedema under combined therapy with
Table 1 Updated diagnostic criteria for tuberous sclerosis complex (TSC; taken from [5], used with permission)

A. Genetic diagnostic criteria

The identification of either a TSC1 or TSC2 pathogenic mutation is sufficient to make a definite diagnosis of TSC. A pathogenic mutation is defined as a mutation that clearly inactivates the function of the TSC1 or TSC2 proteins, prevents protein synthesis, or is a missense mutation whose effect on protein function has been established by functional assessment. Other TSC1 or TSC2 variants whose effect on function is less certain do not meet these criteria, and are not sufficient to make a definite diagnosis of TSC. Note that $10-25 \%$ of TSC patients have no mutation identified by conventional genetic testing, and a normal result does not exclude TSC

B. Clinical diagnostic criteria

Major features

Minor features

1. Hypomelanotic macules $(\geq 3$, at least 5 -mm diameter)

2. Angiofibromas $(\geq 3)$ or fibrous cephalic plaque

3. Ungual fibromas $(\geq 2)$

4. Shagreen patch

5. Multiple retinal hamartomas

6. Cortical dysplasias ${ }^{\mathrm{a}}$

7. Subependymal nodules

8. Subependymal giant cell astrocytoma

9. Cardiac rhabdomyoma

10. Lymphangioleiomyomatosis

$(\mathrm{LAM})^{\mathrm{b}}$

11. Angiomyolipomas $(\geq 2)$

Definite diagnosis: two major features or one major feature with at least two minor features

Possible diagnosis: either one major feature or at least two minor features

${ }^{\mathrm{a}}$ Includes tubers and cerebral white matter radial migration lines

${ }^{b}$ A combination of the two major clinical features Lymphangioleimyomatosis (LAM) and angiomyolipomas without other features does not meet the criteria for a definite diagnosis of TSC

mTORi and ACEi in kidney transplant recipients [50]. There is no recommendation on the evaluation of proteinuria. This may be an essential parameter in the detection of early kidney damage.

\section{Updated treatment recommendations}

\section{Renal manifestations}

In the case of angiomyolipomas larger than 3.5 to $4 \mathrm{~cm}$, renal arterial embolization followed by corticosteroids, or kidneysparing surgery, is used to avoid total nephrectomy [3, 41, 82]. However, even embolization and kidney-sparing surgery have a high incidence of complications and increased risk of CKD, related to nephron loss. Recently, it has been demonstrated that pharmacological intervention using mTORi can obviate the need for surgery by reducing angiomyolipoma volume 
[83-87]. In a randomized, double-blind, placebo-controlled phase III trial (EXIST-2), Bissler et al. offered definitive evidence of the efficacy of everolimus for the treatment of angiomyolipomas in adults with TSC, with an acceptable safety profile [88]. To date, no trials have been performed in children.

According to the 2012 recommendations for the management of angiomyolipomas, embolization followed by corticosteroids is still the first-line therapy when presenting with acute hemorrhage. For asymptomatic, growing angiomyolipomas measuring $>3 \mathrm{~cm}$ in diameter, treatment with an mTORi is recommended as the most effective firstline therapy in the short term [83-85, 88]. However, more studies are needed to confirm the long-term benefits and safety of this treatment strategy.

\section{Extrarenal manifestations}

Traditionally, the management of SEGAs that are growing and/or causing clinical signs of intracranial hypertension or unexplained changes in neurological status or TAND symptoms, was surgical resection [89]. Data on the efficacy and safety of SEGA surgery, as well as on outcome, are very limited and variable [90-93]. SEGA surgery is associated with significant morbidity such as hemiparesis, hydrocephalus, intracranial bleeding, infection, precocious puberty, neuropathic headache and cognitive decline, and mortality $(6.2 \%)$. Individuals at risk are those with symptomatic and/ or bilateral SEGAs, SEGAs measuring $>2 \mathrm{~cm}$ or patients younger than 3 years of age [94]. Moreover, not all SEGAs are amenable for safe and complete resection because of their location. An increasing number of studies and reports have shown that mTORi can induce regression of SEGAs, even in young children [7, 94-96]. According to the 2012 recommendations, surgical resection should be performed for acutely symptomatic SEGA. For growing but otherwise asymptomatic SEGA, either surgical resection or treatment with mTORi can be effective. Everolimus is approved by the European Medicines Agency (EMA) and the Food and Drug Administration (FDA) for use in TSC patients with SEGA requiring therapeutic intervention who are not amenable to surgery [97].

mTORi also have beneficial effects on all the other clinical features of TSC. Topical treatment of facial angiofibromas with sirolimus has extensively been reported to yield positive results [6]. In selected LAM patients with moderate-to-severe lung disease or rapid progression, treatment with an mTORi may be used to stabilize or improve lung function, quality of life, and functional performance [83-85, 98]. Recently, it has been demonstrated that everolimus has a partial effect on epilepsy, decreasing the frequency and severity of seizures [96, 99]. A phase III study assessing the efficacy of everolimus on seizures in TSC patients is currently ongoing (NCT01070316; www.clinicaltrials.gov).

\section{Future perspectives}

The purpose of the 2012 International TSC Consensus Conference was to provide recommendations to help standardize the approach to the management of TSC patients regardless of age or severity of the disease. However, some of the surveillance recommendations can be challenging to follow, e.g., the need for frequent general anesthesia for serial brain and abdominal MRI in mentally retarded patients. Since angiomyolipomas have the potential to produce vascular collagen (i.e., collagen IV) and vascular endothelial growth factor-D (VEGF-D), these surrogate biomarkers were used in a few studies to assess disease burden and to monitor clinical response to treatment of angiomyolipoma [83, 88, 98]. A clear correlation has been noted between these biomarkers and angiomyolipoma volume. Inclusion of these and other biomarkers in future clinical trials might yield new non-invasive methods of monitoring disease progression and response to therapy and potentially to limit the use of MRI.

Despite the enormous progress made in the field of TSC over the past decade, there is a significant lack of long-term data (e.g., on renal outcome). Recently, longitudinal databases such as the European TSC Registry (TOSCA) and the TSC Natural History Database in the USA have been including data on all the organs involved. These are indispensable in shedding more light on the outcome of this population and in improving their care.

\section{Conclusions}

Tuberous sclerosis complex is characterized by the involvement of multiple organs at different stages in life. This population requires management by a specialized multidisciplinary team involving a neurologist, a nephrologist, an urologist, a pulmonologist, an ophthalmologist, a cardiologist, and a dermatologist for pediatric and adult patients. An experienced TSC center and the organization of transition clinics are highly recommended, also enabling adequate enrollment in clinical trials and international TSC registries. mTORi have become a very promising treatment option for TSC patients, although their place is yet to be determined as the first-line treatment. Currently, an individualized approach is recommended, and patients treated with mTORi should be followed carefully with particular attention to potential toxicities. 
Key summary points

1. Tuberous sclerosis complex is a heterogeneous disease affecting almost all organ systems, justifying a multidisciplinary clinical review of these patients.

2. Renal involvement is the second most significant cause of morbidity and mortality in TSC patients, mainly resulting in angiomyolipomas and renal cystic disease.

3. Surveillance of renal involvement in TSC should consist of 1 - to 3-yearly imaging using abdominal MRI (or ultrasound/CT) and annual blood pressure, proteinuria, and renal function assessment.

4. The first-line treatment for acute hemorrhage from angiomyolipomas is arterial embolization followed by corticosteroids. For asymptomatic, growing angiomyolipomas measuring $>3 \mathrm{~cm}$ in diameter, treatment with an mTORi is recommended as the most effective first-line therapy.

Multiple choice questions (answers are provided following reference list)

1. Mutational analysis of TSC1 and TSC2 is negative in a patient with a shagreen patch and multiple renal angiomyolipomas measuring $3 \mathrm{~cm}$ in diameter.
a) The diagnosis of TSC is excluded.
b) The diagnosis of TSC is suspected.
c) The diagnosis of TSC is definite.
d) Mutational analysis should be repeated.

2. Abdominal MRI shows a renal fat-poor lesion measuring $4 \mathrm{~cm}$ that has been stable in growth for 2 years. What action do you take?
a) Plan kidney-sparing surgery.
b) Perform a needle biopsy.
c) Plan an abdominal MRI in 6 months' time.
d) Plan an abdominal ultrasound in 6 months' time.

3. A patient with TSC presents to the emergency unit with a bleeding angiomyolipoma. What action do you take?
a) Perform kidney-sparing surgery.
b) Perform a total nephrectomy.
c) Perform embolization followed by corticosteroid therapy.
d) Treat the patient with an mTORi.

4. What are the new recommendations for the preferred surveillance of renal lesions in TSC?
a) Renal ultrasound every 1 to 3 years
b) $\mathrm{CT}$ of the abdomen every 1 to 3 years
c) MRI of the abdomen every 1 to 3 years
d) Blood pressure and renal function assessment every 1 to 3 years.

5. Everolimus is a potential target treatment for TSC because it
a) Inhibits the activation of mTOR
b) Inhibits the overactivation of mTOR
c) Inhibits the cell cycle
d) Inhibits the formation of blood vessels

Acknowledgements Djalila Mekahli is supported by the Research Foundation Flanders (FWO), Clinical Fellowship (1700613 N).

Conflict of interests None.

\section{References}

1. van Slegtenhorst M, de Hoogt R, Hermans C, Nellist M, Janssen B, Verhoef S, Lindhout D, van den Ouweland A, Halley D, Young J, Burley M, Jeremiah S, Woodward K, Nahmias J, Fox M, Ekong R, Osborne J, Wolfe J, Povey S, Snell RG, Cheadle JP, Jones AC, Tachataki M, Ravine D, Sampson JR, Reeve MP, Richardson P, Wilmer F, Munro C, Hawkins TL, Sepp T, Ali JB, Ward S, Green AJ, Yates JR, Kwiatkowska J, Henske EP, Short MP, Haines JH, Jozwiak S, Kwiatkowski DJ (1997) Identification of the tuberous sclerosis gene TSC1 on chromosome 9q34. Science 277:805-808

2. Sancak O, Nellist M, Goedbloed M, Elfferich P, Wouters C, MaatKievit A, Zonnenberg B, Verhoef S, Halley D, van den Ouweland A (2005) Mutational analysis of the TSC1 and TSC2 genes in a diagnostic setting: genotype-phenotype correlations and comparison of diagnostic DNA techniques in tuberous sclerosis complex. Eur J Hum Genet 13:731-741

3. Curatolo P, Bombardieri R, Jozwiak S (2008) Tuberous sclerosis. Lancet 372:657-668

4. Crino PB, Nathanson KL, Henske EP (2006) The tuberous sclerosis complex. N Engl J Med 355:1345-1356

5. Northrup H, Krueger DA; International Tuberous Sclerosis Complex Consensus Group (2013) Tuberous sclerosis complex diagnostic criteria update: recommendations of the 2012 International Tuberous Sclerosis Complex Consensus Conference. Pediatr Neurol 49:243-254

6. Krueger DA, Northrup H: International Tuberous Sclerosis Complex Consensus Group (2013) Tuberous sclerosis complex surveillance and management: recommendations of the 2012 International Tuberous Sclerosis Complex Consensus Conference. Pediatr Neurol 49:255-265

7. Franz DN (2013) Everolimus in the treatment of subependymal giant cell astrocytomas, angiomyolipomas, and pulmonary and skin lesions associated with tuberous sclerosis complex. Biologics 7:211-221

8. Pirson Y (2013) Tuberous sclerosis complex-associated kidney angiomyolipoma: from contemplation to action. Nephrol Dial Transplant 28:1680-1685 
9. Stillwell TJ, Gomez MR, Kelalis PP (1987) Renal lesions in tuberous sclerosis. J Urol 138:477-481

10. Tsai JD, Wei CC, Chen SM, Lue KH, Sheu JN (2014) Association between the growth rate of renal cysts/angiomyolipomas and age in the patients with tuberous sclerosis complex. Int Urol Nephrol 46: $1685-1690$

11. Dabora SL, Jozwiak S, Franz DN, Roberts PS, Nieto A, Chung J, Choy YS, Reeve MP, Thiele E, Egelhoff JC, Kasprzyk-Obara J, Domanska-Pakiela D, Kwiatkowski DJ (2001) Mutational analysis in a cohort of 224 tuberous sclerosis patients indicates increased severity of TSC2, compared with TSC1, disease in multiple organs. Am J Hum Genet 68:64-80

12. Rakowski SK, Winterkorn EB, Paul E, Steele DJ, Halpern EF, Thiele EA (2006) Renal manifestations of tuberous sclerosis complex: incidence, prognosis, and predictive factors. Kidney Int 70:1777-1782

13. Bernstein J, Robbins TO (1991) Renal involvement in tuberous sclerosis. Ann N Y Acad Sci 615:36-49

14. Kennelly MJ, Grossman HB, Cho KJ (1994) Outcome analysis of 42 cases of renal angiomyolipoma. J Urol 152:1988-1991

15. Lemaitre L, Robert Y, Dubrulle F, Claudon M, Duhamel A, Danjou P, Mazeman E (1995) Renal angiomyolipoma: growth followed up with CT and/or US. Radiology 197:598-602

16. Steiner MS, Goldman SM, Fishman EK, Marshall FF (1993) The natural history of renal angiomyolipoma. J Urol 150: $1782-1786$

17. O'Callaghan FJ, Noakes MJ, Martyn CN, Osborne JP (2004) An epidemiological study of renal pathology in tuberous sclerosis complex. BJU Int 94:853-857

18. Ewalt DH, Sheffield E, Sparagana SP, Delgado MR, Roach ES (1998) Renal lesion growth in children with tuberous sclerosis complex. J Urol 160:141-145

19. Pode D, Meretik S, Shapiro A, Caine M (1985) Diagnosis and management of renal angiomyolipoma. Urology 25:461-467

20. Ou YC, Wu HC, Yang CR, Chang CL, Hwang TI, Chang CH (1991) Renal angiomyolipoma: experience of 23 patients. Zhonghua Yi Xue Za Zhi (Taipei) 48:217-223

21. Casper KA, Donnelly LF, Chen B, Bissler JJ (2002) Tuberous sclerosis complex: renal imaging findings. Radiology 225:451-456

22. Bissler JJ, Racadio J, Donnelly LF, Johnson ND (2002) Reduction of postembolization syndrome after ablation of renal angiomyolipoma. Am J Kidney Dis 39:966-971

23. Adler J, Greweldinger J, Litzky G (1984) “Macro" aneurysm in renal angiomyolipoma: two cases, with therapeutic embolization in one patient. Urol Radiol 6:201-203

24. Mouded IM, Tolia BM, Bernie JE, Newman HR (1978) Symptomatic renal angiomyolipoma: report of 8 cases, 2 with spontaneous rupture. J Urol 119:684-688

25. Kessler OJ, Gillon G, Neuman M, Engelstein D, Winkler H, Baniel J (1998) Management of renal angiomyolipoma: analysis of 15 cases. Eur Urol 33:572-575

26. Yamakado K, Tanaka N, Nakagawa T, Kobayashi S, Yanagawa M, Takeda K (2002) Renal angiomyolipoma: relationships between tumor size, aneurysm formation, and rupture. Radiology 225:78-82

27. Franz DN, Bissler JJ, McCormack FX (2010) Tuberous sclerosis complex: neurological, renal and pulmonary manifestations. Neuropediatrics 41:199-208

28. Siroky BJ, Yin H, Bissler JJ (2011) Clinical and molecular insights into tuberous sclerosis complex renal disease. Pediatr Nephrol 26: $839-852$

29. Bernstein J (1993) Renal cystic disease in the tuberous sclerosis complex. Pediatr Nephrol 7:490-495

30. Bissler JJ, Siroky BJ, Yin H (2010) Glomerulocystic kidney disease. Pediatr Nephrol 25:2049-2056

31. Brook-Carter PT, Peral B, Ward CJ, Thompson P, Hughes J, Maheshwar MM, Nellist M, Gamble V, Harris PC, Sampson JR (1994) Deletion of the TSC2 and PKD1 genes associated with severe infantile polycystic kidney disease-a contiguous gene syndrome. Nat Genet 8:328-332

32. Kozlowski P, Roberts P, Dabora S, Franz D, Bissler J, Northrup H, Au KS, Lazarus R, Domanska-Pakiela D, Kotulska K, Jozwiak S, Kwiatkowski DJ (2007) Identification of 54 large deletions/ duplications in TSC1 and TSC2 using MLPA, and genotypephenotype correlations. Hum Genet 121:389-400

33. Sampson JR, Maheshwar MM, Aspinwall R, Thompson P, Cheadle JP, Ravine D, Roy S, Haan E, Bernstein J, Harris PC (1997) Renal cystic disease in tuberous sclerosis: role of the polycystic kidney disease 1 gene. Am J Hum Genet 61:843-851

34. Siracusano S, Zanon M, D’Aloia G, Plaino F, Trombetta C, Bussani R (1998) Rare association of renal angiomyolipoma and oncocytoma. Urology 51:837-839

35. Zerban H, Nogueira E, Riedasch G, Bannasch P (1987) Renal oncocytoma: origin from the collecting duct. Virchows Arch B Cell Pathol Incl Mol Pathol 52:375-387

36. Amin MB, Crotty TB, Tickoo SK, Farrow GM (1997) Renal oncocytoma: a reappraisal of morphologic features with clinicopathologic findings in 80 cases. Am J Surg Pathol 21:1-12

37. Eble JN, Hull MT (1984) Morphologic features of renal oncocytoma: a light and electron microscopic study. Hum Pathol 15:1054-1061

38. Al-Saleem T, Wessner LL, Scheithauer BW, Patterson K, Roach ES, Dreyer SJ, Fujikawa K, Bjornsson J, Bernstein J, Henske EP (1998) Malignant tumors of the kidney, brain, and soft tissues in children and young adults with the tuberous sclerosis complex. Cancer 83:2208-2216

39. Lane BR, Aydin H, Danforth TL, Zhou M, Remer EM, Novick AC, Campbell SC (2008) Clinical correlates of renal angiomyolipoma subtypes in 209 patients: classic, fat poor, tuberous sclerosis associated and epithelioid. J Urol 180:836-843

40. Patel U, Simpson E, Kingswood JC, Saggar-Malik AK (2005) Tuberose sclerosis complex: analysis of growth rates aids differentiation of renal cell carcinoma from atypical or minimal-fat-containing angiomyolipoma. Clin Radiol 60:665-673

41. Dixon BP, Hulbert JC, Bissler JJ (2011) Tuberous sclerosis complex renal disease. Nephron Exp Nephrol 118:e15-e20

42. Balligand JL, Pirson Y, Squifflet JP, Cosyns JP, Alexandre GP, van Ypersele de Strihou C (1990) Outcome of patients with tuberous sclerosis after renal transplantation. Transplantation 49:515-518

43. Sarraf M, Masoumi A, Castro-Silva FJ, Myers JB, Wilson SS, Schrier RW (2009) A case of tuberous sclerosis complex that progressed to end-stage renal disease. Nat Clin Pract Nephrol 5:172-176

44. de Chadarevian JP, Legido A, Miles DK, Katsetos CD (2003) Epilepsy, atherosclerosis, myocardial infarction, and carbamazepine. J Child Neurol 18:150-151

45. Shepherd CW, Gomez MR, Lie JT, Crowson CS (1991) Causes of death in patients with tuberous sclerosis. Mayo Clin Proc 66:792-796

46. Rouviere O, Nivet H, Grenier N, Zini L, Lechevallier E (2012) Guidelines for the management of tuberous sclerosis complex renal disease. Prog Urol 22:367-379

47. Ecder T, Schrier RW (2009) Cardiovascular abnormalities in autosomal-dominant polycystic kidney disease. Nat Rev Nephrol 5: 221-228

48. Cadnapaphornchai MA, McFann K, Strain JD, Masoumi A, Schrier RW (2008) Increased left ventricular mass in children with autosomal dominant polycystic kidney disease and borderline hypertension. Kidney Int 74:1192-1196

49. Orskov B, Romming Sorensen V, Feldt-Rasmussen B, Strandgaard S (2010) Improved prognosis in patients with autosomal dominant polycystic kidney disease in Denmark. Clin J Am Soc Nephrol 5: 2034-2039

50. Duerr M, Glander P, Diekmann F, Dragun D, Neumayer HH, Budde K (2010) Increased incidence of angioedema with ACE inhibitors in combination with mTOR inhibitors in kidney transplant recipients. Clin J Am Soc Nephrol 5:703-708 
51. Wong M (2008) Mechanisms of epileptogenesis in tuberous sclerosis complex and related malformations of cortical development with abnormal glioneuronal proliferation. Epilepsia 49: $8-21$

52. Grajkowska W, Kotulska K, Jurkiewicz E, Matyja E (2010) Brain lesions in tuberous sclerosis complex. Folia Neuropathol 48:139-149

53. Cuccia V, Zuccaro G, Sosa F, Monges J, Lubienieky F, Taratuto AL (2003) Subependymal giant cell astrocytoma in children with tuberous sclerosis. Childs Nerv Syst 19:232-243

54. Goh S, Butler W, Thiele EA (2004) Subependymal giant cell tumors in tuberous sclerosis complex. Neurology 63:1457-1461

55. Adriaensen ME, Schaefer-Prokop CM, Stijnen T, Duyndam DA, Zonnenberg BA, Prokop M (2009) Prevalence of subependymal giant cell tumors in patients with tuberous sclerosis and a review of the literature. Eur J Neurol 16:691-696

56. Campen CJ, Porter BE (2011) Subependymal giant cell astrocytoma (SEGA) treatment update. Curr Treat Options Neurol 13:380-385

57. Beaumont TL, Limbrick DD, Smyth MD (2012) Advances in the management of subependymal giant cell astrocytoma. Childs Nerv Syst 28:963-968

58. Thiele EA (2004) Managing epilepsy in tuberous sclerosis complex. J Child Neurol 19:680-686

59. Chu-Shore CJ, Major P, Camposano S, Muzykewicz D, Thiele EA (2010) The natural history of epilepsy in tuberous sclerosis complex. Epilepsia 51:1236-1241

60. Curatolo P, Jozwiak S, Nabbout R, SEGA TSCCMf, Epilepsy M (2012) Management of epilepsy associated with tuberous sclerosis complex (TSC): clinical recommendations. Eur J Paediatr Neurol 16: 582-586

61. de Vries PJ, Hunt A, Bolton PF (2007) The psychopathologies of children and adolescents with tuberous sclerosis complex (TSC): a postal survey of UK families. Eur Child Adolesc Psychiatry 16:1624

62. de Vries PJ, Prather PA (2007) The tuberous sclerosis complex. N Engl J Med 356:92

63. Prather P, de Vries PJ (2004) Behavioral and cognitive aspects of tuberous sclerosis complex. J Child Neurol 19:666-674

64. Cudzilo CJ, Szczesniak RD, Brody AS, Rattan MS, Krueger DA, Bissler JJ, Franz DN, McCormack FX, Young LR (2013) Lymphangioleiomyomatosis screening in women with tuberous sclerosis. Chest 144:578-585

65. Franz DN, Brody A, Meyer C, Leonard J, Chuck G, Dabora S, Sethuraman G, Colby TV, Kwiatkowski DJ, McCormack FX (2001) Mutational and radiographic analysis of pulmonary disease consistent with lymphangioleiomyomatosis and micronodular pneumocyte hyperplasia in women with tuberous sclerosis. Am J Respir Crit Care Med 164:661-668

66. Harding CO, Pagon RA (1990) Incidence of tuberous sclerosis in patients with cardiac rhabdomyoma. Am J Med Genet 37:443-446

67. Holley DG, Martin GR, Brenner JI, Fyfe DA, Huhta JC, Kleinman CS, Ritter SB, Silverman NH (1995) Diagnosis and management of fetal cardiac tumors: a multicenter experience and review of published reports. J Am Coll Cardiol 26:516-520

68. Fricke BL, Donnelly LF, Casper KA, Bissler JJ (2004) Frequency and imaging appearance of hepatic angiomyolipomas in pediatric and adult patients with tuberous sclerosis. AJR Am J Roentgenol 182: 1027-1030

69. Parry L, Maynard JH, Patel A, Clifford SC, Morrissey C, Maher ER, Cheadle JP, Sampson JR (2001) Analysis of the TSC1 and TSC2 genes in sporadic renal cell carcinomas. Br J Cancer 85:1226-1230

70. Qin W, Chan JA, Vinters HV, Mathern GW, Franz DN, Taillon BE, Bouffard P, Kwiatkowski DJ (2010) Analysis of TSC cortical tubers by deep sequencing of TSC1, TSC2 and KRAS demonstrates that small second-hit mutations in these genes are rare events. Brain Pathol 20:1096-1105
71. Lieberthal W, Levine JS (2012) Mammalian target of rapamycin and the kidney. II. Pathophysiology and therapeutic implications. Am J Physiol Renal Physiol 303:F180-F191

72. Lieberthal W, Levine JS (2012) Mammalian target of rapamycin and the kidney. I. The signaling pathway. Am J Physiol Renal Physiol 303:F1-F10

73. Augustine JJ, Bodziak KA, Hricik DE (2007) Use of sirolimus in solid organ transplantation. Drugs 67:369-391

74. Stenner-Liewen F, Grunwald V, Greil R, Porta C (2013) The clinical potential of temsirolimus in second or later lines of treatment for metastatic renal cell carcinoma. Expert Rev Anticancer Ther 13: $1021-1033$

75. Torres VE, Harris PC (2009) Autosomal dominant polycystic kidney disease: the last 3 years. Kidney Int 76:149-168

76. Kenerson HL, Aicher LD, True LD, Yeung RS (2002) Activated mammalian target of rapamycin pathway in the pathogenesis of tuberous sclerosis complex renal tumors. Cancer Res 62:5645-5650

77. Roach ES, Gomez MR, Northrup H (1998) Tuberous sclerosis complex consensus conference: revised clinical diagnostic criteria. J Child Neurol 13:624-628

78. Halpenny D, Snow A, McNeill G, Torreggiani WC (2010) The radiological diagnosis and treatment of renal angiomyolipomacurrent status. Clin Radiol 65:99-108

79. Lienert AR, Nicol D (2012) Renal angiomyolipoma. BJU Int 110 [Suppl 4]:25-27

80. Lemaitre L, Claudon M, Dubrulle F, Mazeman E (1997) Imaging of angiomyolipomas. Semin Ultrasound CT MR 18:100-114

81. Chung MS, Choi HJ, Kim MH, Cho KS (2014) Comparison of T2weighted MRI with and without fat suppression for differentiating renal angiomyolipomas without visible fat from other renal tumors. AJR Am J Roentgenol 202:765-771

82. Sooriakumaran P, Gibbs P, Coughlin G, Attard V, Elmslie F, Kingswood C, Taylor J, Corbishley C, Patel U, Anderson C (2010) Angiomyolipomata: challenges, solutions, and future prospects based on over 100 cases treated. BJU Int 105:101-106

83. Dabora SL, Franz DN, Ashwal S, Sagalowsky A, DiMario FJ Jr, Miles D, Cutler D, Krueger D, Uppot RN, Rabenou R, Camposano S, Paolini J, Fennessy F, Lee N, Woodrum C, Manola J, Garber J, Thiele EA (2011) Multicenter phase 2 trial of sirolimus for tuberous sclerosis: kidney angiomyolipomas and other tumors regress and VEGF- D levels decrease. PLoS One 6:e23379

84. Davies DM, de Vries PJ, Johnson SR, McCartney DL, Cox JA, Serra AL, Watson PC, Howe CJ, Doyle T, Pointon K, Cross JJ, Tattersfield AE, Kingswood JC, Sampson JR (2011) Sirolimus therapy for angiomyolipoma in tuberous sclerosis and sporadic lymphangioleiomyomatosis: a phase 2 trial. Clin Cancer Res 17: 4071-4081

85. Bissler JJ, McCormack FX, Young LR, Elwing JM, Chuck G, Leonard JM, Schmithorst VJ, Laor T, Brody AS, Bean J, Salisbury S, Franz DN (2008) Sirolimus for angiomyolipoma in tuberous sclerosis complex or lymphangioleiomyomatosis. N Engl J Med $358: 140-151$

86. Cabrera Lopez C, Marti T, Catala V, Torres F, Mateu S, Ballarin Castan J, Torra Balcells R (2011) Effects of rapamycin on angiomyolipomas in patients with tuberous sclerosis. Nefrologia 31:292-298

87. Kingswood JC, Jozwiak S, Belousova ED, Frost MD, Kuperman RA, Bebin EM, Korf BR, Flamini JR, Kohrman MH, Sparagana SP, Wu JY, Brechenmacher T, Stein K, Berkowitz N, Bissler JJ, Franz DN (2014) The effect of everolimus on renal angiomyolipoma in patients with tuberous sclerosis complex being treated for subependymal giant cell astrocytoma: subgroup results from the randomized, placebo-controlled, Phase 3 trial EXIST-1. Nephrol Dial Transplant 29:1203-1210

88. Bissler JJ, Kingswood JC, Radzikowska E, Zonnenberg BA, Frost M, Belousova E, Sauter M, Nonomura N, Brakemeier S, de Vries PJ, Whittemore VH, Chen D, Sahmoud T, Shah G, Lincy J, Lebwohl D, 
Budde K (2013) Everolimus for angiomyolipoma associated with tuberous sclerosis complex or sporadic lymphangioleiomyomatosis (EXIST-2): a multicentre, randomised, double-blind, placebocontrolled trial. Lancet 381:817-824

89. Ouyang T, Zhang N, Benjamin T, Wang L, Jiao J, Zhao Y, Chen J (2014) Subependymal giant cell astrocytoma: current concepts, management, and future directions. Childs Nerv Syst 30:561-570

90. Jiang T, Jia G, Ma Z, Luo S, Zhang Y (2011) The diagnosis and treatment of subependymal giant cell astrocytoma combined with tuberous sclerosis. Childs Nerv Syst 27:55-62

91. Sun P, Krueger D, Liu J, Guo A, Rogerio J, Kohrman M (2012) Surgical resection of subependymal giant cell astrocytomas (SEGAs) and changes in SEGA-related conditions: a US national claims database study. Curr Med Res Opin 28:651-656

92. Amin S, Carter M, Edwards RJ, Pople I, Aquilina K, Merrifield J, Osborne JP, O'Callaghan FJ (2013) The outcome of surgical management of subependymal giant cell astrocytoma in tuberous sclerosis complex. Eur J Paediatr Neurol 17:36-44

93. Pascual-Castroviejo I (2011) Neurosurgical treatment of tuberous sclerosis complex lesions. Childs Nerv Syst 27:1211-1219

94. Kotulska K, Borkowska J, Roszkowski M, Mandera M, Daszkiewicz P, Drabik K, Jurkiewicz E, Larysz-Brysz M, Nowak K, Grajkowska W, Domanska-Pakiela D, Jozwiak S (2014) Surgical treatment of subependymal giant cell Astrocytoma in tuberous sclerosis complex patients. Pediatr Neurol 50:307-312

95. Krueger DA, Care MM, Holland K, Agricola K, Tudor C, Mangeshkar P, Wilson KA, Byars A, Sahmoud T, Franz DN (2010) Everolimus for subependymal giant-cell astrocytomas in tuberous sclerosis. N Engl J Med 363:1801-1811

96. Perek-Polnik M, Jozwiak S, Jurkiewicz E, Perek D, Kotulska K (2012) Effective everolimus treatment of inoperable, lifethreatening subependymal giant cell astrocytoma and intractable epilepsy in a patient with tuberous sclerosis complex. Eur J Paediatr Neurol 16:83-85

97. Jozwiak S, Nabbout R, Curatolo P, participants of the TSC Consensus Meeting for SEGA and Epilepsy Management (2013) Management of subependymal giant cell astrocytoma (SEGA) associated with tuberous sclerosis complex (TSC): clinical recommendations. Eur J Paediatr Neurol 17:348-352

98. McCormack FX, Inoue Y, Moss J, Singer LG, Strange C, Nakata K, Barker AF, Chapman JT, Brantly ML, Stocks JM, Brown KK, Lynch JP, 3rd, Goldberg HJ, Young LR, Kinder BW, Downey GP, Sullivan EJ, Colby TV, McKay RT, Cohen MM, Korbee L, Taveira-DaSilva AM, Lee HS, Krischer JP, Trapnell BC; National Institutes of Health Rare Lung Diseases Consortium; MILES Trial Group (2011) Efficacy and safety of sirolimus in lymphangioleiomyomatosis. N Engl J Med 364: 1595-1606

99. Cardamone M, Flanagan D, Mowat D, Kennedy SE, Chopra M, Lawson JA (2014) Mammalian target of rapamycin inhibitors for intractable epilepsy and subependymal giant cell astrocytomas in tuberous sclerosis complex. J Pediatr 164: $1195-1200$

\section{Answers to questions}

1. c

2. c

3. c

4. c

5. b 